\title{
The Prerequisites for a Degrowth Paradigm Shift Insights from Critical Political Economy
}

\author{
Buch-Hansen, Hubert
}

Document Version

Accepted author manuscript

Published in:

Ecological Economics

DOI:

10.1016/j.ecolecon.2017.10.021

Publication date:

2018

\section{License \\ CC BY-NC-ND}

Citation for published version (APA):

Buch-Hansen, H. (2018). The Prerequisites for a Degrowth Paradigm Shift: Insights from Critical Political

Economy. Ecological Economics, 146, 157-163. https://doi.org/10.1016/j.ecolecon.2017.10.021

Link to publication in CBS Research Portal

\section{General rights}

Copyright and moral rights for the publications made accessible in the public portal are retained by the authors and/or other copyright owners and it is a condition of accessing publications that users recognise and abide by the legal requirements associated with these rights.

Take down policy

If you believe that this document breaches copyright please contact us (research.lib@cbs.dk) providing details, and we will remove access to the work immediately and investigate your claim. 


\section{The Prerequisites for a Degrowth Paradigm Shift: Insights from Critical Political Economy Hubert Buch-Hansen}

Journal article (Accepted manuscript*)

\section{Please cite this article as:}

Buch-Hansen, H. (2018). The Prerequisites for a Degrowth Paradigm Shift: Insights from Critical Political

Economy. Ecological Economics, 146, 157-163. https://doi.org/10.1016/j.ecolecon.2017.10.021

DOI: 10.1016/j.ecolecon.2017.10.021

* This version of the article has been accepted for publication and undergone full peer review but has not been through the copyediting, typesetting, pagination and proofreading process, which may lead to differences between this version and the publisher's final version AKA Version of Record.

(1) 2019. This manuscript version is made available under the CC-BY-NC-ND 4.0 license http://creativecommons.org/licenses/by-nc-nd/4.0/ 


\title{
The prerequisites for a degrowth paradigm shift: insights from critical political economy ${ }^{1}$
}

\begin{abstract}
What would it take for a degrowth paradigm shift to take place? Drawing on contemporary critical political economy scholarship, this article identifies four prerequisites for socio-economic paradigm shifts: deep crisis, an alternative political project, a comprehensive coalition of social forces promoting the project in political struggles, and broad-based consent. It is argued that, on the one hand, there is much to suggest that current crises cannot be resolved under existing institutional frameworks and that degrowth is a political project that provides solutions to some of the key problems currently facing humanity. On the other hand, the prospects for a degrowth paradigm shift remain bleak: unlike political projects that became hegemonic in the past, degrowth has neither support from a comprehensive coalition of social forces nor any consent to its agenda among the broader population.
\end{abstract}

Keywords: crisis; critical political economy; institutional change; degrowth; paradigm shift; political projects

\section{Introduction}

What does it take for deep socio-economic change to take place? Finding answers to this question is of the utmost importance to any social movement hoping to bring about profound changes in the way the economic system functions. Degrowth is one such movement (Demaria et al., 2013). Its vision of a democratic transition towards a smaller economic system that operates within ecological boundaries and that is also socially sustainable 
entails profound socio-economic changes (Boonstra \& Joosse, 2013; G Kallis, 2011; Latouche, 2009). Such changes have not yet taken place, even though many of the ideas underpinning degrowth appeared several decades ago. While countless initiatives that resonate with degrowth have emerged at the local level (see, e.g., D'Alisa et al., 2015; Joutsenvirta, 2016), the degrowth movement has, thus far, had negligible impact on the functioning of the wider economic system.

Nonetheless, in existing scholarship on degrowth, there is surprisingly little discussion either of why degrowth remains politically marginalized or of what it would take for the desired "paradigm shift" to materialize. The present article addresses these issues by drawing on contemporary critical (historical materialist) political economy scholarship. Such scholarship has illuminated a variety of important transformations, including the evolution of transnational power relations (Cox, 1987; Ougaard, 2016), profound regulatory changes (Buch-Hansen \& Wigger, 2011; Horn, 2012), foreign policy developments (van Apeldoorn \& de Graaff, 2015) and - more generally - shifts from one type of capitalism to another (McDonough et al., 2010; Robinson, 2004). While critical political economy scholarship is an indispensable resource for understanding changes in and of capitalism, it is a resource that has rarely been utilized in growth-critical research (albeit see Buch-Hansen, 2014; Klitgaard, 2013; Koch, 2015). This is unfortunate because, as this article seeks to show, the two fields of knowledge have great potential to enrich one another.

This article proceeds as follows. The first section explains how contemporary critical political economy - primarily the strand of transnational historical materialism - explains deep institutional change. Four prerequisites for socio-economic paradigm shifts are distilled from 
critical political economy scholarship and then related to degrowth in the following sections in an attempt to determine the prospects of a degrowth paradigm shift. A brief conclusion sums up the argument.

\section{The political economy of paradigm shifts}

Key theoretical frameworks in contemporary critical political economy - such as regulation theory (Bieling et al., 2016; Boyer, 1990; Staricco, 2015), the social structures of accumulation approach (Gordon et al., 1982; McDonough et al., 2010) and transnational historical materialism (Cox, 1987; Overbeek, 2013) - all seek to explain when and why institutional and societal changes take place. Such frameworks underscore that capitalism is crisis-prone because of its conflictual nature: as a result of class conflicts and numerous other contradictions (Harvey, 2014), the process of capital accumulation (the engine of capitalism) can only be temporarily stabilised by means of various institutional arrangements. The institutions stabilising the capital accumulation process at the micro-

level, thereby facilitating growth at the macro-level, have been referred to as "social structures of accumulation" (Gordon et al., 1982).

Such institutions are the outcomes of political struggles. Importantly, political struggles are, in this view, not just a matter of processes in parliaments. Critical political economists consider the social forces engendered by the capitalist production process, namely fractions of capital and labour, to be the most important drivers of social change. As already noted by Marx (1963: 704), society 'by no means consists only of two classes, workers and industrial 
capitalists'. Fractions thus become a key concept here. The defining feature of a class fraction is that its "members" perform similar economic functions in the process of capital accumulation. As a result, they tend to have specific ideological inclinations that are organically related to these functions (van der Pijl, 1998). Class struggle is, therefore, not merely something that involves capitalists versus workers; it is also a phenomenon that occurs within the basic classes and between fractions with vastly different outlooks and preferences.

One axis along which the fractionalisation of capital can take place is that of industrial versus money capital, with members of the latter fraction having a much more liberal outlook than those of the former (Overbeek, 1990: 25-27). Other axes of fractioning are those of monopoly versus non-monopoly capital (Poulantzas, 1975: 144-145) and nationally versus transnationally oriented capital (Robinson, 2004; van Apeldoorn, 2002). The power balance between different fractions is closely related to prevailing accumulation structures. For instance, if capital accumulation is predominantly transnational, transnational capital fractions will tend to prevail. Over time, social forces undergo transformations through dialectical interplays with the capitalist system itself, and in this process, power relations change and deep institutional change becomes possible (Wigger and Buch-Hansen, 2014; see also Tickell and Peck, 1992). The relative power of different social forces often changes in the wake of deep crises of capitalism. Such crises mark the end of previously prevailing social structures of accumulation and associated social forces, and they pave the way for the ascendance of new social forces and ideas (Cox, 1987; Overbeek \& van der Pijl, 1993). 
A class fraction can seek to shape overall societal developments by advancing a political project that outlines a way out of an ongoing crisis. ${ }^{2}$ Class fractions will thus attempt to mobilise support for their political project by entering into various forms of alliances with other fractions, political parties, business associations, labour unions and/or other organisations. In liberal democracies, broad-based consent, or at least passive consent, is an additional precondition for a political project to become institutionalised. In terms of their content, political projects present ways of dealing 'with current contradictions in the labour, intersectoral/competition, and profit distribution processes, as well as with broader social and political issues' (van der Pijl, 1998: 4). ${ }^{3}$ So-called "organic intellectuals" (Gramsci, 1971: 5-23) play a key role in the process of devising and lending legitimacy to political projects. Associated with the very social class whose interests they seek to advance, organic intellectuals can be a broad range of actors, including, for instance, (social) scientists, think tanks, journalists, business(wo)men, political advisors and party strategists (van Apeldoorn, 2002: 31). A political project has become hegemonic once the ideas it incorporates have become "common sense", 'bringing about not only a unison of economic and political aims, but also intellectual and moral unity' (Gramsci, 1971: 181).

According to Overbeek (1999: 248-9), political projects that become hegemonic generally go through three phases: deconstruction, construction, and consolidation. As an illustration, these phases can be considered in relation to neoliberalism - a political project that, in the words of van Apeldoorn \& Overbeek (2012: 5), 'is characterized by a mix of liberal promarket and supply-side discourses (laissez-faire, privatization, liberalization, deregulation, competitiveness) and of monetarist orthodoxy (price stability, balanced budgets, austerity)'. The ascendancy of neoliberalism initially occurred against the backdrop of the deep 
economic crisis of the 1970s, which also constituted a crisis of the then hegemonic Keynesian project (see also Kotz \& McDonough, 2010). In this first phase, neoliberalism served as a "deconstructive project" that provided intellectual ammunition for the disruption of the post-World War Two social order of embedded liberalism/social democracy. Neoclassical economists and right-wing (organic) intellectuals such as Friedrich von Hayek and Milton Friedman played an important role in questioning existing institutional arrangements and in devising the emerging neoliberal project (Peck, 2010). This project was primarily centred around the interest of the fraction of transnational financial capital (Overbeek \& van der Pijl, 1993).

In the second "constructive" phase of neoliberalism, its proponents succeeded, to a considerable extent, in elevating neoliberal discourses to the status of being the only credible and legitimate ideas around. In this phase, neoliberal discourses thus informed a series of reforms of existing institutional arrangements. Van Apeldoorn and Overbeek (2012: 5) observe that '[t]he coalition of social forces whose fractional interests are articulated through these discourses is configured around the hegemonic fraction of transnational finance capital; it comprises not only the leading sections of the financial sector and a large segment of the leading transnational corporations, but also key segments of the "new middle classes" and of organized labour.' By contrast, the post-war social order of embedded liberalism had been based on a compromise between nationally oriented industrial capital and organised labour. The rise of neoliberalism was, as such, premised on tectonic shifts in the balance of power between social forces, which were, in turn, related to the transnationalisation of the capitalist system (on the rise of neoliberalism, see also Duménil and Lévy, 2011; Harvey, 2010). 
In its third phase, neoliberalism became hegemonic in most parts of the capitalist world. Although neoliberal ideas had been implemented in various ways and to different degrees in different countries (Brenner et al., 2010), the neoliberal paradigm shift had - overall been accomplished at this juncture. From a critical political economy perspective, then, a paradigm shift has taken place once one hegemonic project has been replaced by another. Importantly, in such a third phase of consolidation, 'crucial path dependencies are created. Interests become entrenched, ideologies become internalized, and in this manner institutional and ideological blockages arise that prevent an adequate response to emerging contradictions in later phases' (van Apeldoorn and Overbeek, 2012: 7).

No political project is hegemonic forever. As mentioned, the social structures of accumulation (perhaps) brought about by the institutionalisation of political projects can only temporarily stabilise the capital accumulation process. At some point, contradictions begin to surface, a crisis commences, and - increasingly - the proponents of alternative political projects challenge the hitherto prevailing project (see also McDonough, 2011). Because policy-makers and other agents interpret reality - including the causes of and solutions to a crisis - on the basis of ideas, the availability of one or more alternative political projects is a precondition for a crisis to be succeeded by a paradigm shift. However, again, an alternative paradigm only becomes hegemonic if it attracts support from a comprehensive coalition of social forces. Importantly, it is generally not the case that a new paradigm immediately becomes hegemonic and that new social structures of accumulation are swiftly established. Paradigm shifts take time and are rare, one reason being the aforementioned path dependencies, which serve to ensure that political struggles to advance specific political 
projects do not take place in a neutral terrain. Instead, they take place within institutional contexts (such as states) that are the crystallisations of previous struggles. Existing institutions are thus "strategically selective", meaning that they tend to privilege certain ideas, actors and strategies over other ideas, actors and strategies (Jessop, 1990). In other words, institutions tend to have a conservative function: for the most part, they work to the benefit of the advocates of already institutionalised ideas.

To recapitulate, contemporary critical political economy identifies a number of prerequisites for a socio-economic paradigm shift: a deep crisis that cannot be solved by the institutional arrangements to which the currently prevailing political project has given shape (prerequisite 1); one or more alternative political projects that show the ways out of the crisis (prerequisite 2); organic intellectuals and a comprehensive alliance of social forces promoting the project in political struggles (prerequisite 3); and broad-based consent, or at least passive consent, for the political project (prerequisite 4). In the following sections, the task is to establish where the degrowth movement stands with respect to these four prerequisites.

\section{Crisis}

Whereas previously in history, the tendency was for major crises to occur roughly one at a time, several deep and intertwined crises are currently unfolding in parallel (Max-Neef, 2014). The 2008 financial crisis may be over, but the economic and social scars it left continue to be deep, and a new financial crisis is already looming. The IMF speaks of a global recovery that is 'weak and precarious' and of the risk of 'stagnation in advanced 
economies' (IMF, 2016b: xiv, xvi). The fragility of the global financial system is underscored in a recent study, in which it is noted that global debt levels are now at an all-time high and that high private debt in the rich countries and in a few 'systemically important emerging market economies [...] increases the likelihood of a financial crisis' (IMF, 2016a: 1).

Contemporary capitalism is also characterised by a social crisis, which is related to growing inequality. The income gaps between the top earners ("the $1 \%$ " and "the $0.1 \%$ ") and the rest of society have become a hotly debated topic in the wake of the 2008 financial crisis as manifested in the emergence of the international Occupy movement and the publication of Thomas Piketty's bestseller Capital in the Twenty-First Century (Piketty, 2014). While the top earners continue to rapidly accumulate more wealth, a large group of bottom earners in many rich countries, this group accounts for up to $40 \%$ of the population - have scarcely benefitted from economic growth and are being left behind (OECD, 2015a). Economic inequality has profound social consequences; for instance, it reduces educational opportunities and lowers the social mobility of many people at the bottom. As the OECD (2015a: 21 ) comments, 'the decline of the $40 \%$ raises social and political questions. When such a large group in the population gains so little from economic growth, the social fabric frays and trust in institutions is weakened.' Income inequality has also increased in many developing countries, and although the number of people living in extreme poverty has been reduced significantly in recent decades (OECD, 2015b: 36), hundreds of millions of people still live in poverty.

Another crisis is the environmental crisis, which encompasses a wide range of factors including, for instance, climate change, biodiversity loss and deforestation - that undermine 
current and future living conditions for human beings and other species (Speth, 2008). The root cause of this crisis is the endless increase in the world's volume of production and in humanity's consumption of the planet's finite resources. To merely sustain humanity's current level of environmental impact, 1.6 planets would be required (WWF, 2016). This figure obviously obscures the fact that whereas there is massive overconsumption in the rich countries of the world, the populations of a number of underdeveloped countries have a real and pressing need to increase their consumption if they are to meet basic human needs.

A host of other actual or impending crises can be mentioned (see, e.g., Brand and Wissen, 2012; Harvey, 2010; Robinson, 2014). In fact, it is likely to be the case that 'never before in human history have so many crises converged simultaneously to reach their maximum level of tension' (Max-Neef, 2014: 17). It seems highly unlikely that these crises - which can also be thought of as one multidimensional crisis - could be resolved under the institutional arrangements of neoliberal capitalism. The 2008 financial crisis was - to no small extent a result of neoliberal policies (Duménil \& Lévy, 2011), and the same can be said of growing inequality (Hall et al., 2013). However, even more fundamentally, the question is whether the crises - not least the environmental crisis - can be resolved simultaneously within the framework of an economic system that needs to grow. So far, there is nothing to suggest that it is even remotely possible to bring humanity's environmental impact down to a sustainable level within such a system (Dietz \& O’Neill, 2013; Jackson, 2009).

To recapitulate, if a deep crisis is an important prerequisite for deep institutional change as not only critical political economists but also many other social scientists suggest - then 
we live in a time when such change ought to be possible. In other words, the first precondition for a degrowth paradigm shift exists.

\section{An alternative political project}

The second precondition for a degrowth paradigm shift is that degrowth constitutes an alternative political project. Although degrowth is not generally conceptualised as a political project - it is more frequently seen as an emerging intellectual paradigm (Martínez-Alier et al., 2010) or as a social movement (Demaria et al., 2013) - it arguably does have key attributes of one. That is, aside from addressing the problems of economic and social injustice and the environmentally unsustainable nature of an economic system that needs to grow endlessly, degrowth presents a general vision of a different form of society as a solution to the current crises. Unlike the supporters of the prevailing neoliberal policy paradigm (and for that matter, of the previously prevailing Keynesian paradigm), who consider increased economic growth to be the solution to most societal problems, advocates of degrowth maintain that moving towards an overall smaller economic system that functions within ecological boundaries is both desirable and necessary. Far from suggesting that all dimensions of all economic spaces have to "degrow", however, they highlight that 'some sectors, such as education, medical care, or renewable energy, will need to flourish in the future, while others, such as dirty industries or the financial sector shrink' (Kallis et al., 2015: 5). Moreover, whereas material sacrifices in the rich parts of the world are deemed necessary in order to bring about sustainable low-carbon economies, degrowth proponents 
acknowledge the need for poor countries to develop economically (Demaria et al., 2013; Kallis et al., 2012).

Kallis et al. (2015: 4) envisage a socially equitable "degrowth society" with a smaller metabolism, in which 'everything will be different: different activities, different forms and uses of energy, different relations, different gender roles, different allocations of time between paid and non-paid work, different relations with the non-human world'. What further qualifies degrowth as a political project is that its advocates outline several concrete instruments and policies - at times referred to as "policy proposals" (see Kallis, 2015) - that might contribute to bringing about such a society and to making it work. The proposals are too numerous to be listed here, but some of the most important ones relate to work sharing, minimum and maximum income, social enterprises, localised production, eco-communities, community currencies, debt auditing, time-banks and job guarantees (e.g., D'Alisa et al., 2015; Latouche, 2009).

In important respects, then, degrowth can be considered a political project. Yet, it is also clear that in other respects it deviates significantly from the "conventional" political projects identified in critical political economy scholarship. Van Apeldoorn and Overbeek (2012: 5) write that '[a]ny hegemonic project needs [...] a more or less coherent accumulation strategy serving the interests of the leading capital fraction and their immediate allies'. Clearly degrowth as a political project does not come with an accumulation strategy. To the contrary, it offers a "de-accumulation strategy" and is hardly premised on benefitting any "leading capital fraction". In other words, it is a political project that points beyond (i.e., entails a break with) capitalism and which would, as such, involve not merely a "normal" paradigm shift but 
also an extraordinarily comprehensive transformation of a very broad range of socioeconomic institutions. Degrowth thus represents an interesting case for contemporary critical political economy, the conceptual frameworks of which have predominantly been designed to understand capitalism and socio-economic change within this system. ${ }^{4}$

In this context, it is worth noting that some growth-critical scholars, most notably Lawn (2011), maintain that a non-growing economy is potentially compatible with capitalism. This is, however, a minority view among growth-critics (see Blauwhof, 2012; Klitgaard, 2013), and it is certainly safe to say that there is little in the history of capitalism so far that would indicate the ability of this system to function without growth. Yet, even if a non-growing capitalism could be established, this would not, per se, make it compatible with the degrowth project. Indeed, the degrowth vision of socially equitable societies is arguably directly at odds with capitalism, which - as noted by several critical political economists - is an economic system that is premised on exploitation and which produces inequality (Harvey, 2014; Stanford, 2008; van der Pijl, 1998). To be sure, the extent to which capitalism is exploitative and entails inequality varies in time and space. For instance, the comprehensive social democratic welfare regimes that emerged - as a result of working-class pressure - in some of the world's rich countries in the post-World War Two decades served to reduce inequalities (Esping-Andersen, 1990; Lipietz, 1992). Yet, these welfare regimes, while facilitating high economic growth rates $^{5}$, were still premised on exploitation (Offe, 1984) and unsustainable consumption of natural resources (Brand \& Wissen, 2012; Koch, 2012). These regimes, which have, to a large extent, been subsequently transformed into neoliberal "competition states" (Cerny, 1997), do thus not resonate well with the degrowth vision of an equitable and environmentally sustainable economic system (see also Koch \& Buch- 
Hansen, 2016). On balance, there are strong reasons to believe that degrowth is incompatible with capitalism - that indeed it is 'fundamentally anti-capitalist' (Latouche, 2009: 91).

To recapitulate, degrowth can be considered a political project. To be sure, it is an unconventional project that is still under development, and it is impossible to know how well its policies actually work on a societal level until they have been implemented (this goes for the policies of all new political projects). Nonetheless, it is a political project that presents a reasonably coherent alternative to neoliberal capitalism and which provides ways out of a number of the crises facing humanity. As such, it could well serve as a blueprint for institutional and socio-economic change.

\section{Support from a comprehensive coalition of social forces}

Political projects do not become hegemonic just because they embody good ideas. For a project to become hegemonic, (organic) intellectuals first need to develop the project and a constellation of social forces with sufficient power and resources to implement it then needs to find it appealing and struggle for it. In this context, it is worth noting that degrowth, as a social movement, has been gaining momentum for some time, not least in Southern Europe. Countless grassroots' initiatives (e.g., D'Alisa et al., 2013) are the most visible manifestations that degrowth is on the rise. Intellectuals - including founders of ecological economics such as Nicholas Georgescu-Roegen and Herman Daly, and more recently degrowth scholars such as Serge Latouche and Giorgos Kallis - have played a major role 
in developing and disseminating the ideas underpinning the project. A growing interest in degrowth in academia, as well as well-attended biennial international degrowth conferences, also indicate that an increasing number of people embrace such ideas.

Still, the degrowth project is nowhere near enjoying the degree and type of support it needs if its policies are to be implemented through democratic processes. The number of political parties, labour unions, business associations and international organisations that have so far embraced degrowth is modest to say the least. Economic and political elites, including social democratic parties and most of the trade union movement, are united in the belief that economic growth is necessary and desirable. This consensus finds support in the prevailing type of economic theory and underpins the main contenders in the neoliberal project, such as centre-left and nationalist projects. In spite of the world's multidimensional crisis, a progrowth discourse in other words continues to be hegemonic: it is widely considered a matter of common sense that continued economic growth is required.

It is also noteworthy that economic and political elites, to a large extent, continue to support the neoliberal project, even in the face of its evident shortcomings. Indeed, the 2008 financial crisis did not result in the weakening of transnational financial capital that could have paved the way for a paradigm shift. Instead of coming to an end, neoliberal capitalism has arguably entered a more authoritarian phase (Bruff, 2014). The main reason the power of the precrisis coalition remains intact is that governments stepped in and saved the dominant fraction by means of massive bailouts. It is a foregone conclusion that this fraction and the wider coalition behind the neoliberal paradigm (transnational industrial capital, the middle classes and segments of organised labour) will consider the degrowth paradigm unattractive 
and that such social forces will vehemently oppose the implementation of degrowth policies (see also Rees, 2014: 97).

While degrowth advocates envision a future in which market forces play a less prominent role than they do today, degrowth is not an anti-market project. As such, it can attract support from certain types of market actors. In particular, it is worth noting that social enterprises, such as cooperatives (Restakis, 2010), play a major role in the degrowth vision. Such enterprises are defined by being 'organisations involved at least to some extent in the market, with a clear social, cultural and/or environmental purpose, rooted in and serving primarily the local community and ideally having a local and/or democratic ownership structure' (Johanisova et al., 2013: 11). Social enterprises currently exist at the margins of a system, in which the dominant type of business entity is profit-oriented, shareholder-owned corporations. The further dissemination of social enterprises, which is crucial to the transitions to degrowth societies, is - in many cases - blocked or delayed as a result of the centrifugal forces of global competition (Wigger \& Buch-Hansen, 2013). Overall, social enterprises thus (still) constitute a social force with modest power.

Ougaard (2016: 467) notes that one of the major dividing lines in the contemporary transnational capitalist class is between capitalists who have a material interest in the carbon-based economy and capitalists who have a material interest in decarbonisation. The latter group, for instance, includes manufacturers of equipment for the production of renewable energy (ibid.: 467). As mentioned above, degrowth advocates have singled out renewable energy as one of the sectors that needs to grow in the future. As such, it seems likely that the owners of national and transnational companies operating in this sector would 
be more positively inclined towards the degrowth project than would capitalists with a stake in the carbon-based economy. Still, the prospect of the "green sector" emerging as a driving force behind degrowth currently appears meagre. Being under the control of transnational capital (Harris, 2010), such companies generally embrace the "green growth" discourse, which 'is deeply embedded in neoliberal capitalism' and indeed serves to adjust this form of capitalism 'to crises arising from contradictions within itself' (Wanner, 2015: 23).

In addition to support from the social forces engendered by the production process, a political project 'also needs the political ability to mobilize majorities in parliamentary democracies, and a sufficient measure of at least passive consent' (van Apeldoorn \& Overbeek, 2012: 5-6) if it is to become hegemonic. As mentioned, degrowth enjoys little support in parliaments, and certainly the pro-growth discourse is hegemonic among parties in government. ${ }^{6}$ With capital accumulation being the most important driving force in capitalist societies, political decision-makers are generally eager to create conditions conducive to production and the accumulation of capital (Lindblom, 1977: 172). Capitalist states and international organisations are thus "programmed" to facilitate capital accumulation, and do as such constitute a strategically selective terrain that works to the disadvantage of the degrowth project.

The main advocates of the degrowth project are grassroots, small fractions of left-wing parties and labour unions as well as academics and other citizens who are concerned about social injustice and the environmentally unsustainable nature of societies in the rich parts of the world. The project is thus ideationally driven in the sense that support for it is not so much rooted in the material circumstances or short-term self-interests of specific groups or 
classes as it is rooted in the conviction that degrowth is necessary if current and future generations across the globe are to be able to lead a good life. While there is no shortage of enthusiasts and creative ideas in the degrowth movement, it has only modest resources compared to other political projects. To put it bluntly, the advocates of degrowth do not possess instruments that enable them to force political decision-makers to listen to - let alone comply with - their views. As such, they are in a weaker position than the labour union movement was in its heyday, and they are in a far weaker position than the owners and managers of large corporations are today (on the structural power of transnational corporations, see Gill and Law, 1989).

\section{Consent}

It is also safe to say that degrowth enjoys no "passive consent" from the majority of the population. For the time being, degrowth remains unknown to most people. Yet, if it were to become generally known, most people would probably not find the vision of a smaller

economic system appealing. This is not just a matter of degrowth being 'a missile word that backfires' because it triggers negative feelings in people when they first hear it (Drews \& Antal, 2016). It is also a matter of the actual content of the degrowth project.

Two issues in particular should be mentioned in this context. First, for many, the anticapitalist sentiments embodied in the degrowth project will inevitably be a difficult pill to swallow. Today, the vast majority of people find it almost impossible to conceive of a world without capitalism. There is a 'widespread sense that not only is capitalism the only viable 
political and economic system, but also that it is now impossible to even imagine a coherent alternative to it' (Fisher, 2009: 2). As Jameson (2003) famously observed, it is, in a sense, easier to imagine the end of the world than it is to imagine the end of capitalism. However, not only is degrowth - like other anti-capitalist projects - up against the challenge that most people consider capitalism the only system that can function; it is also up against the additional challenge that it speaks against economic growth in a world where the desirability of growth is considered common sense.

Second, degrowth is incompatible with the lifestyles to which many of us who live in rich countries have become accustomed. Economic growth in the Western world is, to no small extent, premised on the existence of consumer societies and an associated consumer culture most of us find it difficult to completely escape. In this culture, social status, happiness, well-being and identity are linked to consumption (Jackson, 2009). Indeed, it is widely considered a natural right to lead an environmentally unsustainable lifestyle - a lifestyle that includes car ownership, air travel, spacious accommodations, fashionable clothing, an omnivorous diet and all sorts of electronic gadgets. This Western norm of consumption has increasingly been exported to other parts of the world, the result being that never before have so many people taken part in consumption patterns that used to be reserved for elites (Koch, 2012). If degrowth were to be institutionalized, many citizens in the rich countries would have to adapt to a materially lower standard of living. That is, while the basic needs of the global population can be met in a non-growing economy, not all wants and preferences can be fulfilled (Koch et al., 2017). Undoubtedly, many people in the rich countries would experience various limitations on their consumption opportunities as a violent encroachment on their personal freedom. Indeed, whereas many recognize that 
contemporary consumer societies are environmentally unsustainable, fewer are prepared to actually change their own lifestyles to reverse/address this.

At present, then, the degrowth project is in its "deconstructive phase", i.e., the phase in which its advocates are able to present a powerful critique of the prevailing neoliberal project and point to alternative solutions to crisis. At this stage, not enough support has been mobilised behind the degrowth project for it to be elevated to the phases of "construction" and "consolidation". It is conceivable that at some point, enough people will become sufficiently discontent with the existing economic system and push for something radically different. Reasons for doing so could be the failure of the system to satisfy human needs and/or its inability to resolve the multidimensional crisis confronting humanity. Yet, various material and ideational path-dependencies currently stand in the way of such a development, particularly in countries with large middle-classes. Even if it were to happen that the majority wanted a break with the current system, it is far from given that a system based on the ideas of degrowth is what they would demand.

\section{Conclusion: towards a degrowth paradigm shift?}

'A revolutionary politics that can grasp the nettle of endless compound capital accumulation and eventually shut it down as the prime motor of human history requires a sophisticated understanding of how social change occurs' (Harvey, 2010: 228)

Growth-critical scholarship and critical political economy are fields of knowledge with great potential for mutual enrichment. Critical political economy provides a number of important 
insights into the preconditions for deep socio-economic change, whereas degrowth presents critical political economists with a political project the institutionalisation of which would - in all likelihood - require a break with capitalism. To assess the possibilities of a degrowth paradigm shift, the present article has distilled, from critical political economy scholarship, four prerequisites for such a shift. The first is a deep crisis of the existing system and of the prevailing paradigm. The second is an alternative political project. The third is a comprehensive coalition of social forces waging political struggles with a view of making the project hegemonic. The fourth is consent, at least passive consent, in the population. In particular, the two latter prerequisites for a degrowth paradigm shift are currently missing: the degrowth project does not enjoy support from a sufficiently comprehensive coalition of social forces or from the public at large. Although degrowth can be seen to constitute a political project that offers a number of ways out of the multidimensional crisis facing humanity, it remains a rather marginal project, one that is incapable of impacting overall socio-economic developments. In sum, even though the countless degrowth-compatible local initiatives and the increasing interest in degrowth are reasons for cautious optimism, the prospects of a degrowth paradigm shift currently look bleak.

Importantly, there is plenty of room to expand the present analysis of the prerequisites for a degrowth paradigm shift. In this article, the focus has been on genera/ prerequisites for deep socio-economic change, yet many concrete obstacles to and opportunities for degrowth differ from one place to the next. If degrowth transitions were to actually take place, they would have to begin from the diverse institutional arrangements characterising contemporary capitalist societies (Buch-Hansen, 2014). To some extent, these institutions would - as a result of ideational and material path dependencies - shape the institutions 
that succeed them. Degrowth transitions and their outcomes would thus, for instance, not be the same in France, the US and China (Buch-Hansen et al., 2016). By implication, both the analysis of paradigm shift prerequisites and the articulation of the degrowth project could advantageously be adjusted to fit specific contexts. It is also significant that degrowth transitions would begin in societies that are, to a very large extent, transnationally integrated, which could well mean that an additional prerequisite for a paradigm shift is international coordination (see also Chertkovskaya et al., 2017: 202).

It is worth reiterating that degrowth on a societal scale would, in all likelihood, entail a break with the capitalist mode of production. Thus, it is certainly conceivable that such a paradigm shift would be less "smooth" than, say, the shift from embedded liberalism to neoliberalism. Although there is no lack of examples of shifts within capitalism that were anything but gentle, it has probably been far easier for parliaments to - for instance - adopt measures that made capitalism more "flexible" in order to renew the social structures of accumulation than it will be to adopt degrowth measures, which aim to dismantle those structures. The present article has mainly utilised insights from transnational historical materialism, which is a body of research that, in its empirical analyses, tends to focus on transitions within capitalism. Yet, considering what a degrowth paradigm shift would entail, there could be an argument for supplementing the four prerequisites identified in this article with insights from research, in the historical materialist tradition and elsewhere, that focuses on more radical social and institutional change (see also Klitgaard and Krall, 2012).

\section{References}

Bieling, H.-J., Jäger, J., \& Ryner, M. (2016). "Regulation Theory and the Political Economy of the European Union." JCMS: Journal of Common Market Studies, 54(1), 53-69. 
Blauwhof, F. B. (2012). “Overcoming accumulation: Is a capitalist steady-state economy possible?" Ecological Economics2, 84, 254-261.

Boonstra, W. J., \& Joosse, S. (2013). "The Social Dynamics of Degrowth." Environmental Values, 22(2), 171189.

Boyer, R. (1990). The Regulation School: A Critical Introduction. New York: Columbia University Press.

Brand, U., \& Wissen, M. (2012). "Global Environmental Politics and the Imperial Mode of Living: Articulations of State-Capital Relations in the Multiple Crisis." Globalizations, 9(4), 547-560.

Brenner, N., Peck, J., \& Theodore, N. (2010). "Variegated neoliberalization: geographies, modalities, pathways." Global Networks, 10(2), 182-222.

Bruff, I. (2014). "The rise of authoritarian neoliberalism." Rethinking Marxism, 26(1), 113-129.

Buch-Hansen, H. (2014). "Capitalist diversity and de-growth trajectories to steady-state economies." Ecological Economics, 106, 173-179.

Buch-Hansen, H., Pissin, A., \& Kennedy, E. (2016). "Transitions towards degrowth and sustainable welfare: Carbon emission reduction and wealth and income distribution in France, the US and China." In M. Koch \& O. Mont (Eds.), Sustainability and the Political Economy of Welfare. London \& New York: Routledge.

Buch-Hansen, H., \& Wigger, A. (2011). The Politics of European Competition Regulation. A Critical Political Economy Perspective. London \& New York: Routledge.

Cerny, P. G. (1997). "Paradoxes of the Competition State: The Dynamics of Political Globalization." Government and Opposition, 32(2), 251-274.

Chertkovskaya, E., Paulsson, A., Kallis, G., Barca, S., \& D'Alisa, G. (2017). “The vocabulary of degrowth : A roundtable debate." Ephemera, 17(March 2016), 189-208.

Cox, R. W. (1987). Production, Power and World Order. New York: Columbia University Press.

D’Alisa, G., Demaria, F., \& Cattaneo, C. (2013). "Civil and Uncivil Actors for a Degrowth Society." Journal of Civil Society, 9(2), 212-224.

D’Alisa, G., Demaria, F., \& Kallis, G. (Eds.). (2015). Degrowth: A Vocabulary for a New Era. London \& New York: Routledge.

Demaria, F., Schneider, F., Sekulova, F., \& Martinez-Alier, J. (2013). "What is Degrowth? From an Activist Slogan to a Social Movement." Environmental Values, 22(2), 191-215.

Dietz, R., \& O'Neill, D. (2013). Enough is enough. Building a sustainable economy in a world of finite resources. San Francisco: Berrett-Koehler Publishers.

Drews, S., \& Antal, M. (2016). “Degrowth: A 'missile word' that backfires?" Ecological Economics, 126, 182187.

Duménil, G., \& Lévy, D. (2011). The Crisis of Neoliberalism. Cambridge, Massachusetts: Harvard University Press.

Esping-Andersen, G. (1990). The Three Worlds of Welfare Capitalism. Cambridge: Polity Press.

Fisher, M. (2009). Capitalist Realism. Is There No Alternative? Winchester and Washington: O Books.

Gill, S., \& Law, D. (1989). "Global hegemony and the structural power of capital." International Studies Quarterly, 33(4), 475-499.

Gordon, D., Edwards, D., \& Reich, M. (1982). Segmented Work, Divided Workers. Cambridge: Cambridge University Press. 
Gramsci, A. (1971). Selections from Prison Notebooks. London: Lawrence and Wishart.

Hall, S., Massey, D., \& Rustin, M. (2013). “After neoliberalism: analysing the present." Soundings, 53, 8-22.

Harris, J. (2010). "Going green to stay in the black: transnational capitalism and renewable energy." Race \& Class, 52(2), 62-78.

Harvey, D. (2010). The Enigma of Capital and the Crises of Capitalism. London: Profile Books.

Harvey, D. (2014). Seventeen Contradictions and the End of Capitalism. London: Profile Books.

Horn, L. (2012). "After Shareholder Value? Corporate Governance Regulation, the Crisis and Organized Labour at the European Level." In H. Overbeek \& B. Van Apeldoorn (Eds.), Neoliberalism in Crisis (pp. 45-67). New York: Palgrave Macmillan.

IMF. (2016a). Fiscal monitor. Washington, DC: International Monetary Fund.

IMF. (2016b). World Economic Outlook. Washington, DC: International Monetary Fund.

Jackson, T. (2009). Prosperity without growth: Economics for a finite planet. London: Earthscan.

Jameson, F. (2003). "Future City." New Left Review, 21(May-June), 65-79.

Jessop, B. (1990). State Theory. Putting the Capitalist State in its Place. Cambridge: Polity Press.

Johanisova, N., Crabtree, T., \& Frankova, E. (2013). "Social enterprises and non-market capitals: a path to degrowth?" Journal of Cleaner Production, 38, 7-16.

Joutsenvirta, M. (2016). "A practice approach to the institutionalization of economic degrowth." Ecological Economics, 128, 23-32.

Kallis, G. (2011). "In defence of degrowth." Ecological Economics, 70(5), 873-880.

Kallis, G. (2015). "Yes, we can prosper without growth - 10 policy proposals for the New Left." Retrieved June 20, 2017, from https://www.thepressproject.gr/details_en.php?aid=71088

Kallis, G., Demaria, F., \& D’Alisa, G. (2015). “Introduction: Degrowth." In G. D’Alisa, F. Demaria, \& G. Kallis (Eds.), Degrowth. A vocabulary for a new era (pp. 1-17). London \& New York: Routledge.

Kallis, G., Kerschner, C., \& Martinez-Alier, J. (2012). "The economics of degrowth." Ecological Economics, 84, 172-180.

Klitgaard, K. A. (2013). "Heterodox Political Economy and the Degrowth Perspective." Sustainability, 5, 276297.

Klitgaard, K. A., \& Krall, L. (2012). “Ecological economics, degrowth, and institutional change." Ecological Economics, 84, 247-253.

Koch, M. (2012). Capitalism and Climate Change. New York: Palgrave.

Koch, M. (2015). "Climate Change, Capitalism and Degrowth Trajectories to a Global Steady-State Economy." International Critical Thought, 5(4), 439-452.

Koch, M., \& Buch-Hansen, H. (2016). "Human needs, steady-state economics and sustainable welfare." In M. Koch \& O. Mont (Eds.), Sustainability and the Political Economy of Welfare. London \& New York: Routledge.

Koch, M., Buch-Hansen, H., \& Fritz, M. (2017). "Shifting Priorities in Degrowth Research: An Argument for the Centrality of Human Needs." Ecological Economics, 138, 74-81.

Kotz, D. M. (2010). "The Final Conflict: What Can Cause a System-Threatening Crisis of Capitalism?" Science \& Society, 74(3), 362-379.

Kotz, D. M., \& McDonough, T. (2010). "Global neoliberalism and the contemporary social structure of accumulation." In T. McDonough, M. Reich, \& D. M. Kotz (Eds.), Contemporary capitalism and its 
crises: Social structure of accumulation theory for the twenty-first century. Cambridge: Cambridge University Press.

Latouche, S. (2009). Farewell to Growth. Cambridge: Polity Press.

Lawn, P. (2011). "Is steady-state capitalism viable? A review of the issues and an answer in the affirmative." Annals of the New York Academy of Sciences, 1219, 1-25.

Lindblom, C. E. (1977). Politics and Markets. New York: Harper Colophon.

Lipietz, A. (1992). Towards a New Economic Order. Postfordism, Ecology and Democracy. Cambridge: Polity Press.

Martínez-Alier, J., Pascual, U., Vivien, F.-D., \& Zaccai, E. (2010). "Sustainable de-growth: Mapping the context, criticisms and future prospects of an emergent paradigm." Ecological Economics, 69(9), 1741-1747.

Marx, K. (1963). Theories of Surplus-Value. Moscow: Progress Publishers.

Max-Neef, M. (2014). "The world on a collision course and the need for a new economy." In S. Novkovic \& T. Webb (Eds.), Co-operatives in a post-growth era. London: Zed Books.

McDonough, T. (2011). "Social Structures of Accumulation : A 'Punctuated' View of Embeddedness." American Journal of Economics and Sociology, 70(5), 1234-1247.

McDonough, T., Reich, M., \& Kotz, D. M. (Eds.). (2010). Contemporary Capitalism and Its Crises. Cambridge: Cambridge University Press.

OECD. (2015a). In It Together: Why Less Inequality Benefits All. Paris: OECD Publishing.

OECD. (2015b). Income Inequality: The Gap between Rich and Poor. Paris: OECD Publishing.

Offe, C. (1984). Contradictions of the welfare state. London: Hutchinson.

Ougaard, M. (2016). "The reconfiguration of the transnational power bloc in the crisis." European Journal of International Relations, 22(2), 459-482.

Overbeek, H. (1990). Global capitalism and national decline. London: Unwin Hyman.

Overbeek, H. (2013). "Transnational historical materialism." In R. Palan (Ed.), Global Political Economy: Contemporary Theories. London \& New York: Routledge.

Overbeek, H., \& Van der Pijl, K. (1993). "Restructuring capital and restructuring hegemony: neoliberalism and the unmaking of the post-war order." In H. Overbeek (Ed.), Restructuring Hegemony in the Global Political Economy. London and New York: Routledge.

Peck, J. (2010). Constructions of Neoliberal Reason. Oxford: Oxford University Press.

Piketty, T. (2014). Capital in the Twenty-First Century. Cambridge, Massachusetts: Harvard University Press.

Poulantzas, N. (1975). Classes in Contemporary Capitalism. London: NLB.

Rees, W. E. (2014). “Are prosperity and sustainability compatible?" In S. Novkovic \& T. Webb (Eds.), Cooperatives in a post-growth era. London: Zed Books.

Restakis, J. (2010). Humanizing the Economy: Co-operatives in the Age of Capital. Gabriola Island: New Society Pub.

Robinson, W. I. (2004). A Theory of Global Capitalism. Production, Class, and State in a Transnational World. London: Johns Hopkins University Press.

Robinson, W. I. (2014). Global Capitalism and the Crisis of Humanity. Cambridge: Cambridge University Press.

Speth, G. (2008). The Bridge at the Edge of the World. New Haven and London: Yale University Press. 
Stanford, J. (2008). Economics for Everyone. London: Pluto Press.

Staricco, J. I. (2015). Towards a Fair Global Economic Regime? A critical assessment of Fair Trade through the examination of the Argentinean wine industry. Frederiksberg: Copenhagen Business School Phd Series.

Tickell, A., \& Peck, J. (1992). "Accumulation, regulation and the geographies of post-Fordism: missing links in regulationist research." Progress in Human Geography, 16(2), 190-218.

van Apeldoorn, B. (2002). Transnational Capitalism and the Struggle Over European Integration. London and New York: Routledge.

van Apeldoorn, B., \& de Graaff, N. (2015). American Grand Strategy and Corporate Elite Networks: The Open Door since the End of the Cold War. London \& New York: Routledge.

van Apeldoorn, B., \& Overbeek, H. (2012). "Introduction: The Life Course of the Neoliberal Project and the Global Crisis." In B. van Apeldoorn \& H. Overbeek (Eds.), Neoliberalism in Crisis (pp. 1-20). New York: Palgrave.

van der Pijl, K. (1998). Transnational Classes and International Relations. London and New York: Routledge.

Wanner, T. (2015). "The New 'Passive Revolution' of the Green Economy and Growth Discourse: Maintaining the 'Sustainable Development' of Neoliberal Capitalism." New Political Economy, 20(1), 21-41.

Wigger, A., \& Buch-Hansen, H. (2013). “Competition, the global crisis and alternatives to neoliberal capitalism. A critical engagement with anarchism." New Political Science, 35(4), 604-626.

Wigger, A., \& Buch-Hansen, H. (2014). "Explaining (Missing) Regulatory Paradigm Shifts. EU Competition Regulation in Times of Economic Crisis." New Political Economy, 19(1), 113-137.

WWF. (2016). Living Planet Report 2016: Risk and resilience in a new era. Switzerland.

\footnotetext{
${ }^{1}$ This article benefitted greatly from insightful comments by Max Koch, Juan Staricco and two anonymous reviewers. Useful inputs were also received during a seminar on degrowth at the Pufendorf Institute, Lund (December 2015) and during a session on "The structural obstacles to degrowth" at the $5^{\text {th }}$ international degrowth conference, Budapest (September 2016). I am of course entirely responsible for the argument made here and for any omissions and remaining errors.

${ }^{2}$ According to Horn (2012: 48), political projects can be understood as 'concrete and more or less coherent manifestations of social interests with regard to particular socio-economic issues'.

${ }^{3}$ Transnational historical materialists in the tradition of the so-called "Amsterdam perspective" refer to political projects as "concepts of control" and to hegemonic political projects as "comprehensive concepts of control" (Overbeek, 1990; van Apeldoorn, 2002; van der Pijl, 1998). In the present context, the notion of (hegemonic) political projects is used, and this notion is also used when drawing on insights from Amsterdam perspective. ${ }^{4}$ This is, of course, not to deny that critical political economists have, for instance, reflected on whether the turbulence following the 2008 financial meltdown would constitute 'a system-threatening crisis of capitalism' (Kotz, 2010).

${ }^{5}$ Capitalism is not the only economic system that has produced economic growth. In so-called "actually existing socialism", states also championed productivism and economic growth. Degrowth is, as such, also incompatible with this breed of socialism.

${ }^{6}$ However, as pointed out by one of the reviewers, a conference on degrowth and politics is scheduled to take place in the European Parliament in September 2018.
} 